\title{
Taxonomic reorganization of the family Bornaviridae
}

\author{
Jens H. Kuhn · Ralf Dürrwald · Yīmíng Bào · Thomas Briese · Kathryn Carbone • \\ Anna N. Clawson · Joseph L. deRisi - Wolfgang Garten · Peter B. Jahrling • \\ Jolanta Kolodziejek - Dennis Rubbenstroth - Martin Schwemmle • \\ Mark Stenglein $\cdot$ Keizo Tomonaga $\cdot$ Herbert Weissenböck $\cdot$ Norbert Nowotny
}

Received: 14 July 2014/Accepted: 30 October 2014/Published online: 2 December 2014

(C) Springer-Verlag Wien (outside the USA) 2014

\begin{abstract}
Knowledge of bornaviruses has expanded considerably during the last decade. A possible reservoir of mammalian Borna disease virus has been identified, divergent bornaviruses have been detected in birds and reptiles, and endogenous bornavirus-like elements have been discovered in the genomes of vertebrates of several species. Previous sequence comparisons and alignments have indicated that the members of the current family Bornaviridae are phylogenetically diverse and are not adequately classified in the existing bornavirus taxonomy supported by the International Committee on Taxonomy of Viruses (ICTV). We provide an update of these analyses
\end{abstract}

K. Carbone, W. Garten, M. Schwemmle, K. Tomonaga and N. Nowotny are the members of the 2012-2014 International Committee on Taxonomy of Viruses (ICTV) Bornaviridae Study Group.

The taxonomic changes suggested here have not yet been endorsed by the International Committee on Taxonomy of Viruses (ICTV) Executive Committee, may differ from any new taxonomy that is ultimately approved by the ICTV, and are presented for discussion only but have no official standing at the time of publication. An official taxonomic proposal (TaxoProp) to make the changes outlined in this article was submitted to the ICTV on July 2, 2014 (TaxoProp \#2014.010a,bV.N.v1) and was revised after review by the ICTV Executive Committee on September 9, 2014. The final version of the proposal can be found at http://ictvonline.org until it is either fully accepted and ratified or dismissed. At the time of writing, the ICTV Executive Committee had accepted all proposals made and outlined in this article with the exception of that for the newly described "reptilian bornavirus 1". However, until the accepted proposals are ratified, they will have to be seen as tentative. The content of this publication does not necessarily reflect the views or policies of the US Department of Health and Human Services or of the institutions and companies affiliated with the authors.

Electronic supplementary material The online version of this article (doi:10.1007/s00705-014-2276-z) contains supplementary material, which is available to authorized users. and describe their implications for taxonomy. We propose retaining the family name Bornaviridae and the genus Bornavirus but reorganizing species classification. PAirwise Sequence Comparison (PASC) of bornavirus genomes and Basic Local Alignment Search Tool (BLAST) comparison of genomic and protein sequences, in combination with other already published phylogenetic analyses and known biological characteristics of bornaviruses, indicate that this genus should include at least five species: Mammalian 1 bornavirus (classical Borna disease virus and divergent Borna disease virus isolate No/98), Psittaciform 1 bornavirus (avian/psittacine bornaviruses 1, 2, 3, 4, 7), Passeriform 1 bornavirus (avian/canary bornaviruses $\mathrm{C} 1$, C2, C3, LS), Passeriform 2 bornavirus (estrildid finch bornavirus EF), and Waterbird 1 bornavirus (avian bornavirus $062_{\mathrm{CG}}$ ). This classification is also in line with biological characteristics of these viruses and their vertebrate hosts. A snake bornavirus, proposed to be named Loveridge's garter snake virus 1 , should be classified as a member of an additional species (Elapid 1 bornavirus), unassigned to a genus, in the family Bornaviridae. Avian bornaviruses 5, 6, MALL, and another "reptile bornavirus" ("Gaboon viper virus") should stay unclassified until further information becomes available. Finally, we propose new virus names and abbreviations when necessary to achieve clear differentiation and unique identification.

\footnotetext{
J. H. Kuhn $(\bowtie) \cdot$ A. N. Clawson · P. B. Jahrling Integrated Research Facility at Fort Detrick (IRF-Frederick), Division of Clinical Research (DCR), National Institute of Allergy and Infectious Diseases (NIAID), National Institutes of Health (NIH), B-8200 Research Plaza, Fort Detrick, MD, USA e-mail: kuhnjens@mail.nih.gov

R. Dürrwald

IDT Biologika GmbH, Dessau-Rosslau, Germany
} 


\section{History of bornavirus classification and nomenclature}

A disease that we would today consider similar to Borna disease (BD) had been reported since the 19th century in central Europe [2,61]. Although it occurred frequently in several regions of today's Germany, the disease was finally named after the German district of Borna around the town of Borna in Saxony (for an overview see [12]). However, differential intra vitam diagnosis of $\mathrm{BD}$ is challenging to this day, and a first post mortem pathognomonic marker was only introduced with the recognition of Joest-Degen inclusion bodies in 1909 [24]. The viral etiology of BD was established in the 1920s [63, 64]. From then on, the virus was variably referred to as "Bornavirus," "virus of Borna disease" or "Borna virus". Starting in the mid-1970s, "Borna disease virus," abbreviated "BDV", became common parlance, and this name has evolved to become the most used designation for the pathogen.

The first convincing propagation of $\mathrm{BDV}$ in vitro was reported in 1973 [34], but BDV was not mentioned in the First (1971) and Second Reports (1976) of the International Committee on Taxonomy of Viruses (ICTV) [15, 60]. The Third (1979), Fourth (1982), Fifth (1991), and Sixth ICTV Reports (1995) listed BDV as an unclassified virus or virus-like agent $[16,35,36]$. In the 1990s, several scientific breakthroughs made it possible to finally classify BDV. BDV was sequenced $[7,33]$, shown to replicate in the nuclei of infected cells [6], and demonstrated to use the cellular gene splicing machinery for protein expression $[8,49]$. These studies also unequivocally demonstrated that BDV has a monopartite single-stranded RNA genome of negative polarity that is similar in

\section{Y. Bào}

Information Engineering Branch, National Center for Biotechnology Information, National Library of Medicine,

National Institutes of Health, Bethesda, MD, USA

\section{T. Briese}

Center for Infection and Immunity, Mailman School of Public

Health, Columbia University, New York, USA

K. Carbone

National Institutes of Health, Bethesda, Maryland, USA

\section{J. L. deRisi}

Departments of Medicine, Biochemistry and Biophysics, and

Microbiology, University of California, San Francisco, CA, USA

W. Garten

Institute of Virology, Philipps-University Marburg, Marburg, Germany

J. Kolodziejek · N. Nowotny

Department of Pathobiology, Viral Zoonoses, Emerging and Vector-Borne Infections Group, Institute of Virology, University of Veterinary Medicine Vienna, Veterinärplatz 1, 1210 Vienna, Austria organization to members of the order Mononegavirales (which at the time only included the families Filoviridae, Paramyxoviridae, and Rhabdoviridae). However, in contrast to BDV, other mononegaviruses do not make use of gene splicing, and at the time, only nucleorhabdoviruses were known to replicate in the nucleus [23]. In addition, alignment of BDV gene and protein sequences and their regulatory signals with those of other mononegaviruses demonstrated that BDV did not belong to any of the established families [9, 47]. In 1996, the ICTV consequently established a novel mononegavirus family, Bornaviridae, to include a single genus, Bornavirus, for a single species, Borna disease virus (at the time not italicized) [41]. Bornavirus classification and nomenclature has essentially been unchanged since then and was simply repeated in ICTV's Seventh (2000), Eighth (2005), and Ninth (2011) Reports, with the exception of the species Borna disease virus being italicized (Table 1) [10, 50, 51].

\section{Current challenges for bornavirus taxonomy}

The current bornavirus nomenclature is discouraged by the International Code of Virus Classification and Nomenclature

ICVCN Rule 2.1(ii) states that "[t]he essential principles of virus nomenclature are...to avoid or reject the use of names which might cause error or confusion.” ICVCN Rule 3.14 states that "[n]ew names shall not duplicate approved names. New names shall be chosen such that they are not closely similar to names that are in use currently or have

D. Rubbenstroth · M. Schwemmle

Institute for Virology, University Medical Center Freiburg, Freiburg, Germany

M. Stenglein

Department of Microbiology, Immunology and Pathology,

Colorado State University, Fort Collins, Colorado, USA

K. Tomonaga

Institute for Virus Research, Kyoto University, Kyoto, Japan

H. Weissenböck

Department of Pathobiology, Institute of Pathology and Forensic Veterinary Medicine, University of Veterinary Medicine Vienna, Vienna, Austria

N. Nowotny $(\square)$

Department of Microbiology and Immunology,

College of Medicine and Health Sciences, Sultan Qaboos

University, 123 Al-Khoudh, P.O. Box 35, Muscat, Oman

e-mail: nowotny@squ.edu.om

Norbert.Nowotny@vetmeduni.ac.at 
Table 1 Current classification and nomenclature of bornaviruses [51, 57]

\begin{tabular}{llll}
\hline Order (name of taxon members) & $\begin{array}{l}\text { Family (name of taxon } \\
\text { members) }\end{array}$ & $\begin{array}{l}\text { Genus (name of taxon } \\
\text { members) }\end{array}$ & $\begin{array}{c}\text { Species } \\
\text { abbreviation) }\end{array}$ \\
\hline $\begin{array}{l}\text { Mononegavirales (mononegavirads, } \\
\text { mononegaviruses) }\end{array}$ & $\begin{array}{c}\text { Bornaviridae (bornavirids, } \\
\text { bornaviruses) }\end{array}$ & Bornavirus (bornaviruses) & $\frac{\text { Borna disease }}{\text { virus }^{1}}$ \\
\hline
\end{tabular}

${ }_{1}$ Type species is underlined

been in use in the recent past." ICVCN Rule 3.21 states that "[a] species name shall consist of as few words as practicable but be distinct from names of other taxa." ICVCN Rule 3.22 states that "[a] species name must provide an appropriately unambiguous identification of the species" $[1,26]$. Currently, the virus name "Borna disease virus" is identical in spelling with the species name "Borna disease virus" and differs only by typeface (Roman versus italics). Therefore, researchers easily, and commonly, confuse virus and species name in manuscript writing.

\section{Diversity of bornaviruses}

The genomic sequence of BDV detected in mammals is extremely conserved. The vast majority of isolates ("classical BDV" or "BDV1") are > 95\% identical on the genomic nucleotide sequence level [13, 14, 28, 48, 52]. Only one BDV variant, No/98 ("BDV2"), has a genomic sequence that is $85 \%$ similar to the remaining isolates [39]. In 2008, however, viruses clearly related to, but distinct from, BDV were discovered in psittaciform birds with proventricular dilatation disease (PDD) [20, 27]. These viruses were provisionally named "avian bornaviruses (ABVs)" and were assigned to five different "genetic subgroups" or "genotypes" (“ABV1-5") [27]. ABV "strains" share $91-100 \%$ nucleotide sequence identity within a genotype, $68-85 \%$ between genotypes, and 60 $69 \%$ with BDV [27, 40]. Polyclonal anti-BDV-N and antiBDV-P antisera cross-react with ABV particles [62]. Since the initial discovery of ABVs, a total of $14 \mathrm{ABV}$ "genotypes" have been discovered, of which seven come from non-psittaciform birds (anseriform and passeriform birds) [11, 21, 22, 44-46, 58, 59][GenBank no. KJ756399]. An additional "genotype" was identified in a Loveridge's garter snake (Elapsoidea loveridgei) from Tanzania [54], and another possible bornavirus of reptilian origin has yet to be described in detail [17]. Avian bornaviruses replicate less efficiently in mammalian cells compared to mammalian bornaviruses, which grow in both mammalian and avian cell lines [38, 42-46, 53]. An overview of all these novel candidate bornaviruses is presented in Supplementary Table S1. The sequence divergence of these viruses from BDV isolates (see also [19]), association of ABVs with a distinct disease, and identification of ABVs in nonmammalian hosts indicate that these viruses should be classified in taxa different from that of BDV.

New classification and nomenclature

The classification of bornaviruses, like that of most viruses, is challenging because i) new distinct groups of these viruses are continuously being discovered, and ii) the number of complete or coding complete genomic sequences [32] and actual virus isolates is still limited.

We propose here to use objective criteria for the initial classification of bornaviruses based on pairwise genome identity comparisons. The comparisons should then be followed by carefully choosing taxon demarcation cutoffs that a) fit the current understanding of bornavirus diversity based on other phylogenetic analyses, b) fit the available biological characteristics of individual bornaviruses (for instance, differences in host specificity, serological crossreactions, or behavior in in vitro assays), and c) fit the current taxon hierarchy (i.e., do not require the establishment of taxon levels not supported by the ICTV). Ideally, there are no discrepancies between these various types of analysis - however, in case there are discrepancies it will be the task of the ICTV Bornaviridae Study Group to resolve them and find a compromise.

To achieve an objective resolution of bornavirus relationships for the initial step of classification, we employed the PAirwise Sequence Comparison (PASC) methodology $[3,4]$, a tool available from the National Center for 
Biotechnology Information (NCBI) website (http://www. ncbi.nlm.nih.gov/sutils/pasc/viridty.cgi?textpage=overview). PASC is a sequence-based classification method analyzing pairwise identities of the genomes of viruses from a particular family using the global Needleman-Wunsch alignment algorithm with affine scoring model [37]. The NCBI PASC tool creates histograms to visualize the distribution of the number of virus pairs at each identity percentage. A typical result has peaks that represent different taxon levels. The percentages of the lowest points of the valleys between the peaks can be used as taxon demarcation criteria. It is important to point out here that these peaks can be assigned to any taxon level, i.e., that groups of closely related viruses, here represented as groups of highly similar sequences, can be arbitrarily designated species, genera, or families. This could cause a problem for taxonomists if the overall number of peaks obtained during an analysis surpasses the number of ICTVapproved hierarchical levels and is distributed over a large range of percentage identities. On the other hand, if the number of peaks is equal to or below the number of these levels and clustering is close, assignment is straightforward, especially when other phylogenetic data and biological criteria are taken into account additionally.

The results of our bornavirus PASC analysis can be accessed on the PASC webpage (http://www.ncbi.nlm.nih. gov/sutils/pasc/viridty.cgi?cmdresult=main\&id=454) $\quad($ see Supplemental Table S2 for sequences used for PASC and other analyses and Fig. 1 for a screenshot).
This PASC analysis suggested that the following classification would be, at this time, most appropriate for bornaviruses:

- the family should stay monogeneric (with the currently available sequences, the peak in PASC for the most distantly related viruses is located at $61-66 \%$ );

- PASC revealed three potential choices for species differentiation: i) a cutoff of $66-69 \%$; ii) a cutoff of 71$75 \%$; and iii) a cutoff of $76-78 \%$. Based on the divergence of the analyzed viruses in regard to their hosts (mammals, highly divergent clades of birds, and reptiles) (Table S1 and [11, 17, 21, 27, 44-46, 54, 58, 59]), additional phylogenetic analyses (Table $\mathrm{S} 3$ and $[11,17,19,21,27,44-46,58,59])$, and their antigenic dissimilarities [62], choice ii seemed most appropriate. Consequently, the genus should include at least five species based on a nucleotide sequence cutoff of $75 \%$;

- species 1 should encompass classical Borna disease virus ("BDV1");

- BDV isolate No/98 ("BDV2") is an outlier from the other BDV isolates but should be a member of species 1

- species 2 should encompass avian/psittacine bornaviruses 1,2 , and 4 ;

- species 3 should encompass avian/canary bornaviruses $\mathrm{C} 1, \mathrm{C} 2$, and $\mathrm{C} 3$; and

- species 4 should encompass avian/anserine bornavirus $062_{\mathrm{CG}}$

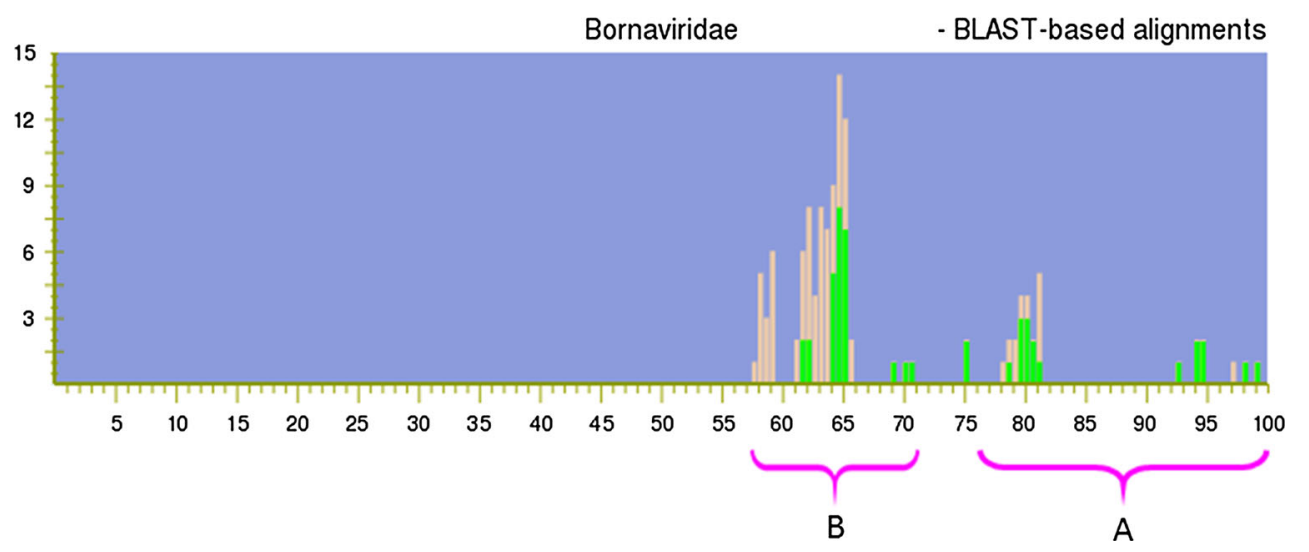

Fig. 1 Distribution of pairwise identities among complete sequences of 16 viruses in the family Bornaviridae. The NCBI PASC alignment tool automatically assigns peak colors (brown, green) based on NCBI virus taxonomy. Regions represent genome pairs belonging to the same species (A) and to different species but to the same genus (B), respectively. Since most of the sequences used for PASC analysis are currently not classified in NCBI taxonomy the same way as proposed in this paper, the colors in this screenshot do not follow the grouping, thereby visually demonstrating that the current bornavirus taxonomy is ill-advised. For instance, bornavirus genomes EU781967 and
FJ620690 are 97\% identical and therefore should belong to the same species in one genus. However, in the current NCBI taxonomy, EU781967 is assigned to the species Borna disease virus in the genus Bornavirus, whereas FJ620690 is assigned to an unclassified species in an unclassified genus in the family Bornaviridae. Therefore, since the NCBI taxonomy tool does not assign both sequences to the same species or the same genus, the bar at $97 \%$ in the current PASC figure is colored brown rather than green. X-axis, percentage of identity; $\mathrm{y}$ axis, number of genome pairs (color figure online) 
- species 5, which for the moment cannot be unambiguously assigned to the genus Bornavirus, should encompass the virus from a Loveridge's garter snake.

If implemented, PASC results would be visualized as depicted in Fig. 2.

We complemented PASC analysis with classical BLAST analyses using each bornavirus protein gene (nt BLAST and protein BLAST; Supplemental Table S3).
These analyses confirm the PASC results and in addition indicate that:

- $\quad$ avian/psittacine bornaviruses 3 and avian bornavirus 7 should be members of species 2 ;

- avian bornaviruses from Bengalese finches (Lonchura striata f. domestica) (avian bornavirus LS) should be a member of species 3;

- a species 6 should encompass avian bornavirus EF; and

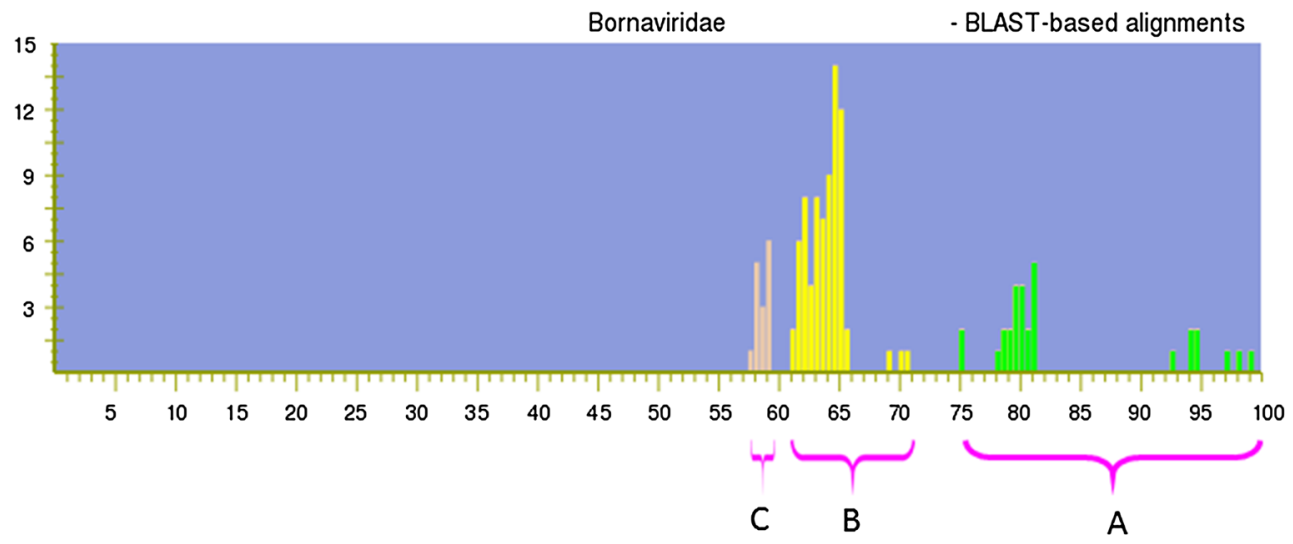

Fig. 2 The same distribution of pairwise identities among complete sequences of 16 viruses in the family Bornaviridae as in Fig. 1, but colored as if the taxonomy proposed in this manuscript was accepted by the ICTV and then adopted by NCBI. Peaks above $75 \%$ identity (region A, green) represent genome pairs belonging to the same species. Peaks between 60 and 71\% identity (region B, yellow) represent genome pairs belonging to different species but the same genus. Peaks below $60 \%$ identity (region $\mathrm{C}$, brown) represent genome pairs that belong to a separate genus (not yet proposed in this manuscript). X-axis, percentage of identity; y-axis, number of genome pairs (color figure online)

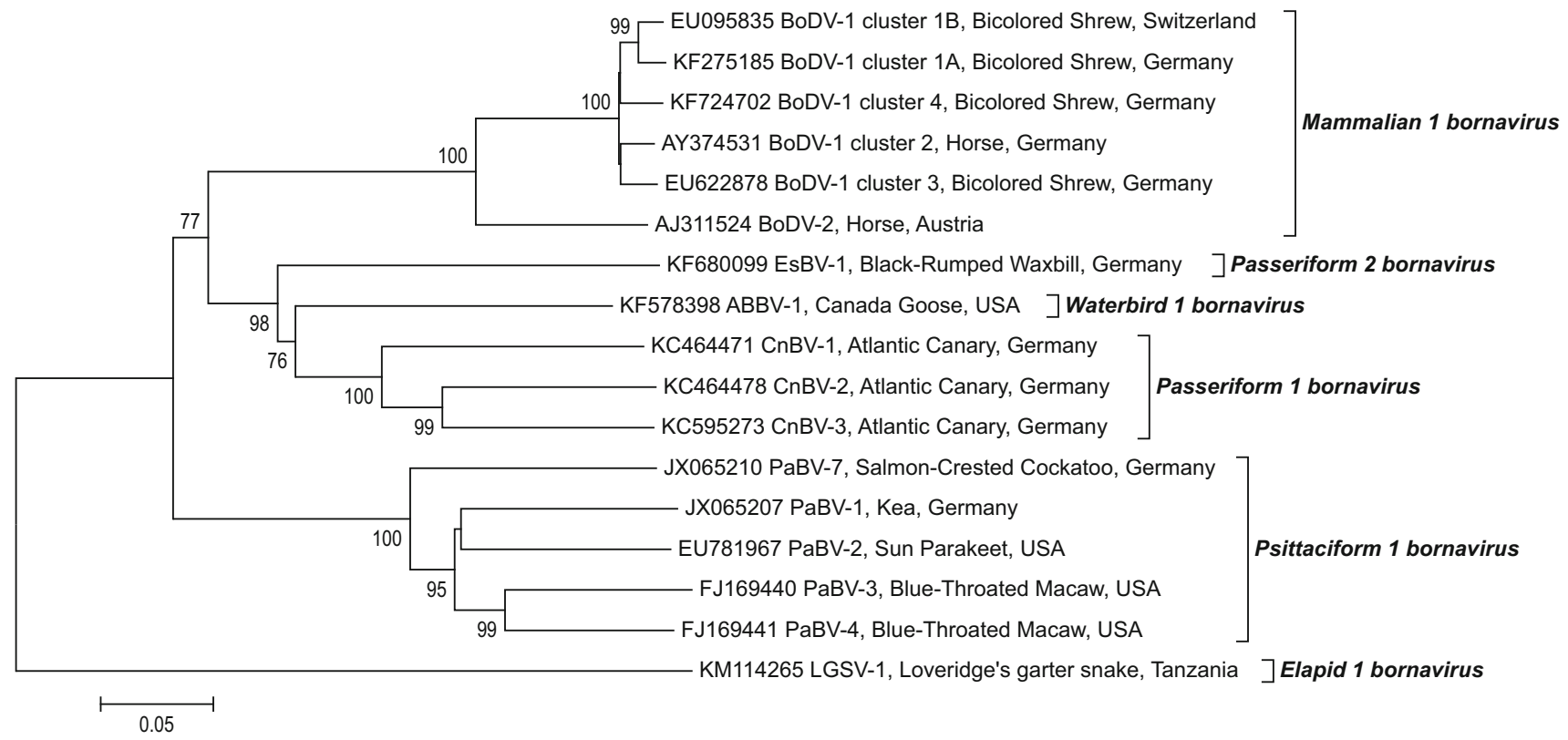

Fig. 3 Phylogenetic tree of a 1824-nt stretch of 17 selected nucleic acid sequences coding for $\mathrm{N}, \mathrm{X}$, and $\mathrm{P}$ proteins and the $\mathrm{N} / \mathrm{X}$ intergenic region of bornaviruses. Phylogenetic neighbor-joining analysis was conducted using the MEGA5 program [55]. The evolutionary distances were computed using the Kimura 2-parameter model. Bootstrap resampling analysis with 1,000 replicates was employed; percentages $\geq 60 \%$ are shown next to the branches 


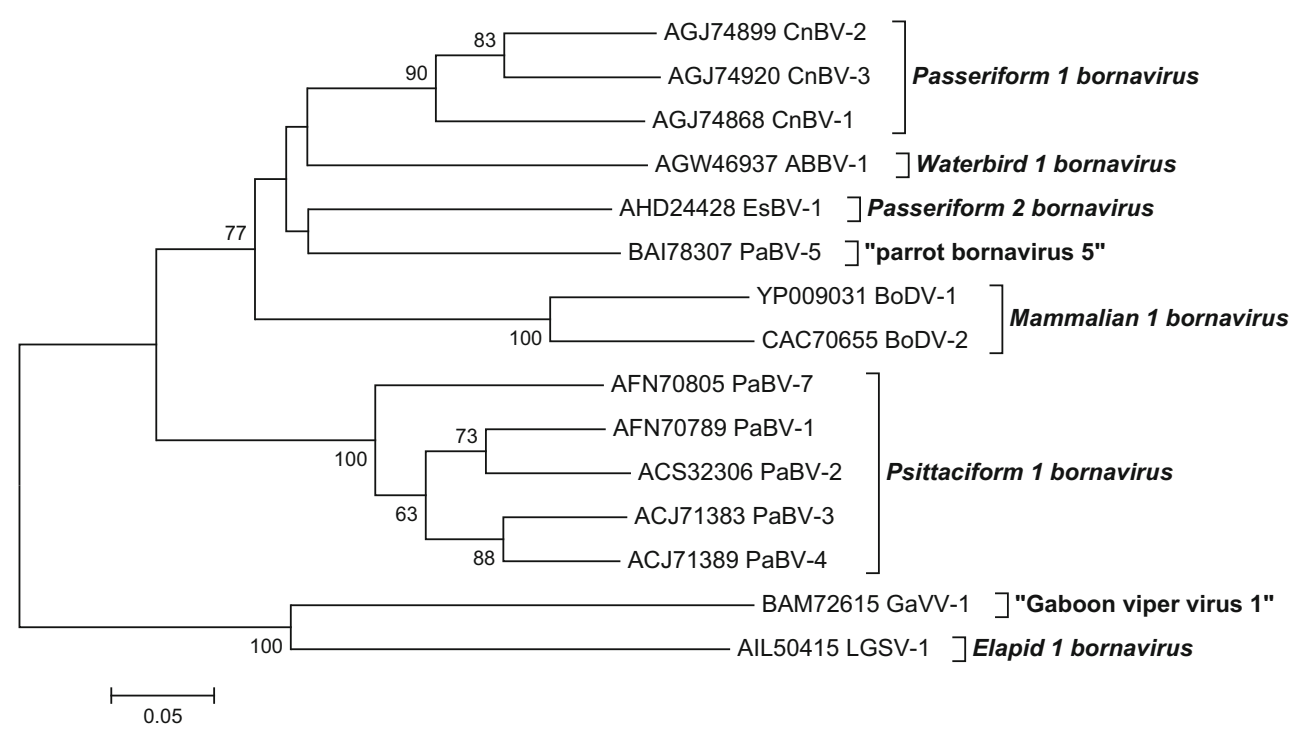

Fig. 4 Phylogenetic tree of 15 selected amino acid sequences representing the $\mathrm{X}$ protein of bornaviruses. Phylogenetic neighborjoining analysis was conducted using the MEGA5 program [55]. The

- avian bornaviruses 5, 6, and MALL, and "reptile bornavirus" ("Gaboon viper virus") cannot be classified at the moment as only fragments of these viruses' genomes have been sequenced and isolates are not available or only sequence information in the absence of further biological characterization has been made available at the time of writing.

Finally, multiple sequence alignments were performed using BioEdit Sequence Alignment Editor Version 7.0.9.0 and verified by Clustal $\mathrm{X}$ (version 1.8). The derived neighbor-joining phylogenetic analyses were conducted with the MEGA5 program [55]. Phylogenetic trees were constructed on 17 selected nucleotide sequences of 1,824 base pairs comprising the information coding for the $\mathrm{N}$ protein, the intergenic region, the $\mathrm{X}$ protein, and the $\mathrm{P}$ protein (GenBank sequences of one virus of each sequence cluster of "classical BDV" and one sequence of each "genotype" of avian bornavirus if available [Fig. 3]). Another phylogenetic tree was constructed using 15 selected amino acid sequences of the $\mathrm{X}$ protein (the protein with the highest variability among bornaviruses) representing one sequence for each cluster and genotype (Fig. 4).

To accommodate these results, we propose the taxonomy outlined in Table 2 (pronunciation guidelines are provided in Table 3). Species 1-6 are named Mammalian 1 bornavirus, Psittaciform 1 bornavirus, Passeriform 1 bornavirus, Waterbird 1 bornavirus, Elapid 1 bornavirus, and Passeriform 2 bornavirus, respectively, to introduce non-Latinized binomial species names [56]. Numbers were placed within evolutionary distances were computed using the p-distance method. Bootstrap resampling analysis with 1,000 replicates was employed; percentages $\geq 60 \%$ are shown next to the branches

rather than after the species name ("Mammalian 1 bornavirus" instead of "Mammalian bornavirus 1") to allow for easier formation of vernacular species member names "mammalian 1 bornaviruses" is easy to use, whereas the use of "mammalian bornaviruses 1" or "mammalian bornavirus $1 \mathrm{~s}$ " could lead to cumbersome grammatical constructions that will most likely be falsely corrected by copy editors not familiar with virus taxonomy. Finally, virus names are changed for clear differentiation, and unique abbreviations (as judged by screening the ICTV's $9^{\text {th }}$ Report [26]) are established: "classical" Borna disease virus is renamed Borna disease virus 1 and Borna disease virus isolate No/98 is renamed Borna disease virus 2. The abbreviation "BDV" is abandoned because it is currently also in use for barley dwarf virus and border disease virus and therefore may cause conflicts especially in electronic databases. Unique abbreviations, BoDV-1 and BoDV-2, are therefore instated for Borna disease virus 1 and 2, respectively. Avian bornaviruses 1-7 are renamed parrot bornaviruses 1-7 (PaBV-1-7); avian bornaviruses $\mathrm{C} 1-\mathrm{C} 3$ and $\mathrm{LS}$ are renamed canary bornaviruses 1-3 (CnBV-1-3) and munia bornavirus 1 (MuBV-1), respectively; avian bornavirus $062_{\mathrm{CG}}$ is renamed aquatic bird bornavirus 1 (ABBV-1); and avian bornavirus EF is renamed estrildid finch bornavirus 1 (EsBV-1). The virus found in a Loveridge's garter snake, (reptile bornavirus 1) is renamed Loveridge's garter snake virus 1 (LGSV-1). LGSV-1 is a member of the family Bornaviridae belonging to a novel species (Elapid 1 bornavirus), but based on insufficient further characterization, we recommend not yet including this species into a genus. 
Table 2 Proposed classification and nomenclature of bornaviruses

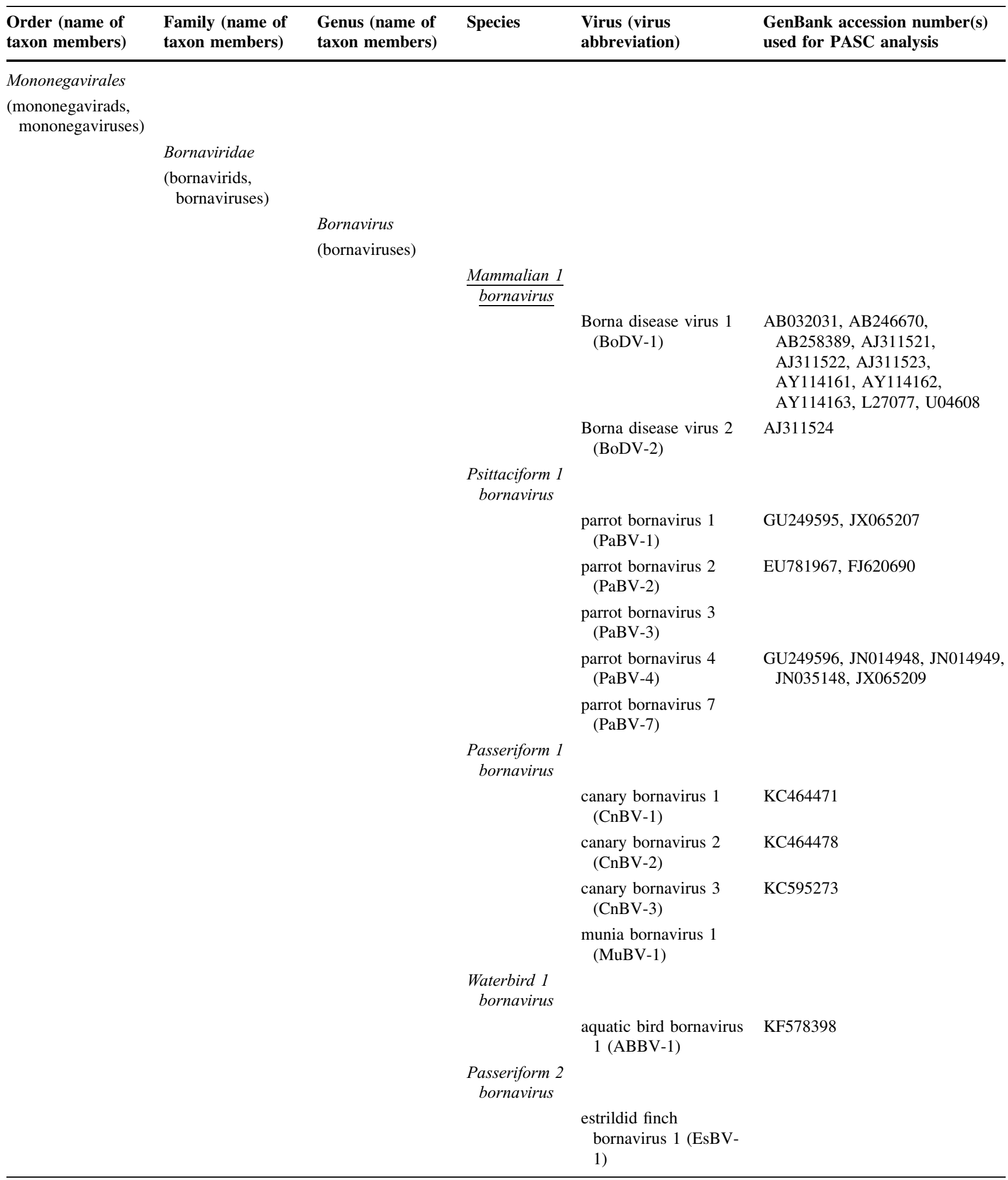


Table 2 continued

\begin{tabular}{|c|c|c|c|c|c|}
\hline $\begin{array}{l}\text { Order (name of } \\
\text { taxon members) }\end{array}$ & $\begin{array}{l}\text { Family (name of } \\
\text { taxon members) }\end{array}$ & $\begin{array}{l}\text { Genus (name of } \\
\text { taxon members) }\end{array}$ & Species & $\begin{array}{l}\text { Virus (virus } \\
\text { abbreviation) }\end{array}$ & $\begin{array}{l}\text { GenBank accession number(s) } \\
\text { used for PASC analysis }\end{array}$ \\
\hline & & $\begin{array}{l}\text { unassigned } \\
\text { bornaviruses }\end{array}$ & & & \\
\hline & & & $\begin{array}{l}\text { Elapid } 1 \\
\text { bornavirus }\end{array}$ & & \\
\hline & & & & $\begin{array}{l}\text { Loveridge's garter } \\
\text { snake virus } 1 \text { (LGSV- } \\
\text { 1) }\end{array}$ & \\
\hline & & $\begin{array}{l}\text { tentative, } \\
\text { unclassified } \\
\text { bornaviruses }\end{array}$ & & & \\
\hline & & & & $\begin{array}{l}\text { avian bornavirus } \\
\text { MALL (ABV- } \\
\text { MALL) }\end{array}$ & \\
\hline & & & & $\begin{array}{l}\text { Gaboon viper virus } 1 \\
(\text { GaVV-1) }\end{array}$ & \\
\hline & & & & $\begin{array}{l}\text { parrot bornavirus } 5 \\
(\mathrm{PaBV}-5)\end{array}$ & \\
\hline & & & & $\begin{array}{l}\text { parrot bornavirus } 6 \\
(\mathrm{PaBV}-6)\end{array}$ & \\
\hline
\end{tabular}

1 Type species is underlined

If a new genus has to be established to accommodate this new virus, a conflict will arise. As the current genus name "Bornavirus" and family name "Bornaviridae" are only differentiated by their suffixes ("-virus" vs. "-viri$d a e$ "), the vernacular names of the members of both taxa are identical (members of the genus Bornavirus are called "bornaviruses"; members of the family Bornaviridae are called "bornaviruses") if taxon-specific suffixes for vernacular names [57] are not used. The inclusion of a second genus in the family would make using the term "bornaviruses" ambiguous, as it would not be clear whether only the members of the genus Bornavirus are meant, or the members of the entire family. Consequently, the name of either the existing family or genus would have to be changed. The current ICTV Bornaviridae Study Group would favor a name change of the family to "Bordiviridae" (for Borna disease) in such a case, as already existing species names would then not have to be changed.

Parrot bornaviruses 5 and 6, "avian bornavirus MALL", and "reptile bornavirus" (tentatively renamed Gaboon viper virus 1; GaVV-1) are members of the family Bornaviridae but will remain unclassified at the species (PaBV-5, PaBV-6, "ABV MALL") and genus level (GaVV-1) until further sequence data become available (see also Supplemental Table 4). In addition, endogenous bornavirus-like elements similar to the $\mathrm{N}, \mathrm{M}$, and $\mathrm{L}$ bornavirus genes that were/are incorporated into the genomes of ancient or current hosts are also deemed unclassifiable for now.

\section{Proposal for nomenclature below the species level}

We propose to adapt the recently published nomenclature scheme for filovirus variants for variants of members of the family Bornaviridae [29-31]. Accordingly, virus variants would be named $<$ virus name $>/(<$ strain $>)<$ isolation host-suffix $>/<$ country of sampling $>/<$ year of sampling $>/<$ genetic variant designation $>-<$ isolate designation $>$. Instructions on how to fill out the individual fields can be found in references [29-31]. Furthermore, we strongly suggest not using the word "strain" indiscriminately for reasons also explained in detail in references 29-31 but instead using "variant". A consortium of bornavirus experts will have to be established under the auspices of the corresponding ICTV Study Group to decide on the precise strain/variant/isolate names for the several hundred bornaviruses currently indexed in databases such as GenBank.

\section{Future prospects}

The family Bornaviridae will most likely have to be expanded in the future. The recent discovery of endogenous bornavirus-like sequences in mammalian and reptilian genomes [5, 18, 21, 22, 25, 65] suggests that the diversity of host distribution of these agents may be much wider than previously appreciated. For this reason, we have proposed a more consistent, logical, and comprehensive classification 
Table 3 Bornavirus and bornavirus taxa pronunciation guidelines

\begin{tabular}{|c|c|c|}
\hline Taxa/Viruses & International Phonetic Alphabet (IPA) & English phonetic notation \\
\hline aquatic bird bornavirus & [ə'kwætık/ə'kwptık b3rd 'bornə,varrəs] & $\begin{array}{l}u h \text {-kwat-ik/uh-kwot-ik burd bawr-n } u h \text {-vahy- } \\
\text { ruhs }\end{array}$ \\
\hline bornavirid & ['bornə, virid] & bawr-n $u h$-vee-rid \\
\hline Bornaviridae & ['bornə, viridi] & bawr-n $u h$-vee-rid-ee \\
\hline bornavirus & ['bornə, vairəs] & bawr-nuh-vahy-ruhs \\
\hline Borna disease virus & ['bornə di' ziz 'vairəs] & bawr-n $u h$ dih-zeez vahy-ruhs \\
\hline Bornavirus & ['bornə, vairəs] & bawr-nuh-vahy-ruhs \\
\hline canary bornavirus & [kə'neəri 'bornə, vairəs] & kuh-nair-ee bawr-n $u h$-vahy-ruhs \\
\hline Elapid 1 bornavirus & ['Eləpıd w $\Lambda$ n 'bornə, varrəs] & el- $u h$-pid wuhn bawr-n $u h$-vahy-r $u h \mathrm{~s}$ \\
\hline estrildid finch bornavirus & ['estrildid fints 'bornə, vairəs] & es-tril-did finch bawr-n $u h$-vahy-r $u h$ s \\
\hline Gaboon viper virus & $\begin{array}{l}\text { [gə'bun/gæ'bun/ga'bun varpər } \\
\text { 'bornə,vaIrəs] }\end{array}$ & $\begin{array}{l}\text { guh-boon/ga-boon/gah-boon vahy-per vahy- } \\
\text { ruhs }\end{array}$ \\
\hline $\begin{array}{l}\text { Loveridge's garter snake } \\
\text { virus }\end{array}$ & 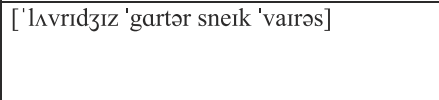 & luhv-ri-jiz gahr-ter sneyk vahy-ruhs \\
\hline Mammalian 1 bornavirus & [mə'merliən wan 'bornə, vaIrəs] & muh-mey-lee-uhn wuhn bawr-n $u h$-vahy-ruhs \\
\hline munia bornavirus & ['munyə/'muniə 'bornə,vairəs] & moo-ny $u h / \mathbf{m o o}-$ nee- $u h$ bawr-n $u h$-vahy-r $u h \mathrm{~s}$ \\
\hline parrot bornavirus & ['pærət 'bornə, varrəs] & par- $u h t$ bawr-n $u h$-vahy-ruhs \\
\hline Passeriform 1 bornavirus & ['pæsəri, form wan 'borno, varrəs] & pas-er-ee-form wuhn bawr-n $u h$-vahy-ruhs \\
\hline Passeriform 2 bornavirus & ['pæsəri, form tu 'bərnə, vairəs] & pas-er-ee-form too bawr-n $u h$-vahy-r $u h \mathrm{~s}$ \\
\hline Psittaciform 1 bornavirus & ['sitəsi, form w wn 'bornə, varrəs] & sit- $u h$-see-form wuhn bawr-n $u h$-vahy-ruhs \\
\hline Waterbird 1 bornavirus & ['wotər, b3rd wan 'bornə, varrəs] & waw-ter-burd wuhn bawr-n $u h$-vahy-ruhs \\
\hline
\end{tabular}

and nomenclature. Naming and classifying novel family members will be easier if rules on how to do that have been established a priori, rather than attempting to adjust or correct problems retrospectively.

Acknowledgments We would like to thank Laura Bollinger and Jiro Wada of the IRF-Frederick for critically editing the manuscript and creating/editing figures. JHK performed this work as an employee of Tunnell Government Services, Inc., and ANC, as the owner of Logos Consulting, Inc., both subcontractors to Battelle Memorial Institute under its prime contract with the National Institutes of Health/National Institute of Allergy and Infectious Diseases, under Contract No. HHSN272200700016I. This research was also supported in part by the Intramural Research Program of the National Institutes of Health, National Library of Medicine (YB).

\section{References}

1. Adams MJ, Lefkowitz EJ, King AM, Carstens EB (2013) Recently agreed changes to the International Code of Virus Classification and Nomenclature. Arch Virol 158:2633-2639

2. Authenrieth CF (1823) Ueber die hitzige Kopf-Krankheit der Pferde. Auf Verlangen des Münsinger Vereins zur Beförderung der Pferdezucht auf der Alp, und zunächst für diese Gegend, bey Heinrich Laupp, Tübingen

3. Bao Y, Kapustin Y, Tatusova T (2008) Virus Classification by Pairwise Sequence Comparison (PASC). In: Mahy BWJ, Regenmortel MHV (eds) Encyclopedia of Virology, 3rd edn. Academic Press, Oxford, pp 342-348

4. Bao Y, Chetvernin V, Tatusova $T$ (2014) Improvements to pairwise sequence comparison (PASC), a genome-based web tool for virus classification. Arch Virol 159:3293-3304 
5. Belyi VA, Levine AJ, Skalka AM (2010) Unexpected inheritance: multiple integrations of ancient bornavirus and ebolavirus/ marburgvirus sequences in vertebrate genomes. PLoS Pathog 6: e1001030

6. Briese T, de la Torre JC, Lewis A, Ludwig H, Lipkin WI (1992) Borna disease virus, a negative-strand RNA virus, transcribes in the nucleus of infected cells. Proc Natl Acad Sci USA 89:1148611489

7. Briese T, Schneemann A, Lewis AJ, Park Y-S, Kim S, Ludwig H, Lipkin WI (1994) Genomic organization of Borna disease virus. Proc Natl Acad Sci USA 91:4362-4366

8. Cubitt B, Oldstone C, Valcarcel J, Carlos de la Torre J (1994) RNA splicing contributes to the generation of mature mRNAs of Borna disease virus, a non-segmented negative strand RNA virus. Virus Res 34:69-79

9. de la Torre JC (1994) Molecular biology of Borna disease virus: prototype of a new group of animal viruses. J Virol 68:76697675

10. de la Torre JC, Carbone K, Staeheli P, Stitz L, Richt JA, Ikuta K, Dietzschold B, Ludwig H, Bode L, Lipkin WI (2000) Family Bornaviridae. In: van Regenmortel MHV, Fauquet CM, Bishop DHL, Carstens EB, Estes MK, Lemon SM, Maniloff J, Mayo MA, McGeoch DJ, Pringle CR, Wickner RB (eds) Virus taxonomy-seventh report of the international committee on taxonomy of viruses. Academic Press, San Diego, pp 531-538

11. Delnatte P, Berkvens C, Kummrow M, Smith DA, Campbell D, Crawshaw G, Ojkic D, DeLay J (2011) New genotype of avian bornavirus in wild geese and trumpeter swans in Canada. Vet Rec 169:108

12. Dürrwald R, Ludwig H (1997) Borna disease virus (BDV), a (zoonotic?) worldwide pathogen. A review of the history of the disease and the virus infection with comprehensive bibliography. J Vet Med B 44:147-184

13. Dürrwald R, Kolodziejek J, Muluneh A, Herzog S, Nowotny N (2006) Epidemiological pattern of classical Borna disease and regional genetic clustering of Borna disease viruses point towards the existence of to-date unknown endemic reservoir host populations. Microbes Infect 8:917-929

14. Dürrwald R, Kolodziejek J, Weissenböck H, Nowotny N (2014) The Bicolored White-Toothed Shrew Crocidura leucodon (HERMANN 1780) Is an Indigenous Host of Mammalian Borna Disease Virus. PLoS One 9:e93659

15. Fenner F (1976) Classification and Nomenclature of VirusesSecond Report of the International Committee on Taxonomy of Viruses. Intervirology 7:1-115

16. Francki RIB, Fauquet CM, Knudson DL, Brown F (1991) Classification and Nomenclature of Viruses - Fifth Report of the International Committee on Taxonomy of Viruses. Archives of Virology Supplement, vol. 2. Springer-Verlag, Vienna, Austria

17. Fujino $K$, Horie $M$, Honda $T$, Nakamura $S$, Matsumoto $Y$, Francischetti IM, Tomonaga K (2012) Evolutionarily conserved interaction between the phosphoproteins and X proteins of bornaviruses from different vertebrate species. PLoS One 7:e51161

18. Gilbert C, Meik JM, Dashevsky D, Card DC, Castoe TA, Schaack S (2014) Endogenous hepadnaviruses, bornaviruses and circoviruses in snakes. Proc Biol Sci 281(1791):2014112. doi:10.1098/ rspb.2014.1122

19. He M, An TZ, Teng CB (2014) Evolution of mammalian and avian bornaviruses. Mol Phylogenet Evol 79C:385-391

20. Honkavuori KS, Shivaprasad HL, Williams BL, Quan P-L, Hornig M, Street C, Palacios G, Hutchison SK, Franca M, Egholm M, Briese T, Lipkin WI (2008) Novel Borna virus in psittacine birds with proventricular dilatation disease. Emerg Infect Dis 14:1883-1886

21. Horie M, Honda T, Suzuki Y, Kobayashi Y, Daito T, Oshida T, Ikuta K, Jern P, Gojobori T, Coffin JM, Tomonaga K (2010)
Endogenous non-retroviral RNA virus elements in mammalian genomes. Nature 463:84-87

22. Horie M, Kobayashi Y, Suzuki Y, Tomonaga K (2013) Comprehensive analysis of endogenous bornavirus-like elements in eukaryote genomes. Philos Trans R Soc Lond B Biol Sci 368:20120499

23. Jackson AO, Dietzgen RG, Goodin MM, Bragg JN, Deng M (2005) Biology of plant rhabdoviruses. Annu Rev Phytopathol 43:623-660

24. Joest E, Degen K (1909) Über eigentümliche Kerneinschlüsse der Ganglienzellen bei der enzootischen Gehirn-Rückenmarksentzündung der Pferde. Z Infkrankh Haustiere 6:348-356

25. Katzourakis A, Gifford RJ (2010) Endogenous viral elements in animal genomes. PLoS Genet 6:e1001191

26. King AMQ, Adams MJ, Carstens EB, Lefkowitz EJ (2011) The International Code of Virus Classification and Nomenclature. In: King AMQ, Adams MJ, Carstens EB, Lefkowitz EJ (eds) Virus Taxonomy - Ninth Report of the International Committee on Taxonomy of Viruses. Elsevier/Academic Press, London, pp 1273-1277

27. Kistler AL, Gancz A, Clubb S, Skewes-Cox P, Fischer K, Sorber K, Chiu CY, Lublin A, Mechani S, Farnoushi Y, Greninger A, Wen CC, Karlene SB, Ganem D, DeRisi JL (2008) Recovery of divergent avian bornaviruses from cases of proventricular dilatation disease: identification of a candidate etiologic agent. Virol J 5:88

28. Kolodziejek J, Dürrwald R, Herzog S, Ehrensperger F, Lussy H, Nowotny N (2005) Genetic clustering of Borna disease virus natural animal isolates, laboratory and vaccine strains strongly reflects their regional geographical origin. J Gen Virol 86:385398

29. Kuhn JH, Bao Y, Bavari S, Becker S, Bradfute S, Brister JR, Bukreyev AA, Chandran K, Davey RA, Dolnik O, Dye JM, Enterlein S, Hensley LE, Honko AN, Jahrling PB, Johnson KM, Kobinger G, Leroy EM, Lever MS, Mühlberger E, Netesov SV, Olinger GG, Palacios G, Patterson JL, Paweska JT, Pitt L, Radoshitzky SR, Saphire EO, Smither SJ, Swanepoel R, Towner JS, van der Groen G, Volchkov VE, Wahl-Jensen V, Warren TK, Weidmann M, Nichol ST (2013) Virus nomenclature below the species level: a standardized nomenclature for natural variants of viruses assigned to the family Filoviridae. Arch Virol 158:301311

30. Kuhn JH, Bao Y, Bavari S, Becker S, Bradfute S, Brister JR, Bukreyev AA, Y. C, Chandran K, Davey RA, Dolnik O, Dye JM, Enterlein S, Gonzalez JP, Formenty P, Freiberg AN, Hensley LE, Honko AN, Ignatyev GM, Jahrling PB, Johnson KM, Klenk HD, Kobinger G, Lackemeyer MG, Leroy EM, Lever MS, Lofts LL, Mühlberger E, Netesov SV, Olinger GG, Palacios G, Patterson JL, Paweska JT, Pitt L, Radoshitzky SR, Ryabchikova EI, Saphire EO, Shestopalov AM, Smither SJ, Sullivan NJ, Swanepoel R, Takada A, Towner JS, van der Groen G, Volchkov VE, WahlJensen V, Warren TK, Warfield KL, Weidmann M, Nichol ST (2013) Virus nomenclature below the species level: a standardized nomenclature for laboratory animal-adapted strains and variants of viruses assigned to the family Filoviridae. Arch Virol 158:1425-1432

31. Kuhn JH, Bào Y, Bavari S, Becker S, Bradfute S, Brauburger K, Rodney Brister J, Bukreyev AA, Caì Y, Chandran K, Davey RA, Dolnik O, Dye JM, Enterlein S, Gonzalez JP, Formenty P, Freiberg AN, Hensley LE, Hoenen T, Honko AN, Ignatyev GM, Jahrling PB, Johnson KM, Klenk HD, Kobinger G, Lackemeyer MG, Leroy EM, Lever MS, Mühlberger E, Netesov SV, Olinger GG, Palacios G, Patterson JL, Paweska JT, Pitt L, Radoshitzky SR, Ryabchikova EI, Saphire EO, Shestopalov AM, Smither SJ, Sullivan NJ, Swanepoel R, Takada A, Towner JS, van der Groen G, Volchkov VE, Volchkova VA, Wahl-Jensen V, Warren TK, 
Warfield KL, Weidmann M, Nichol ST (2014) Virus nomenclature below the species level: a standardized nomenclature for filovirus strains and variants rescued from cDNA. Arch Virol 159:1229-1237

32. Ladner JT, Beitzel B, Chain PS, Davenport MG, Donaldson E, Frieman M, Kugelman J, Kuhn JH, O'Rear J, Sabeti PC, Wentworth DE, Wiley MR, Yu G-Y, The Threat Characterization Consortium, Sozhamannan S, Bradburne C, Palacios G (2014) Standards for sequencing viral genomes in the era of highthroughput sequencing. MBio 5:e01360-01314

33. Lipkin WI, Travis GH, Carbone KM, Wilson MC (1990) Isolation and characterization of Borna disease agent cDNA clones. Proc Natl Acad Sci U S A 87:4184-4188

34. Ludwig TH, Becht H, Groh L (1973) Borna disease (BD), a slow virus infection. Biological properties of the virus. Med Microbiol Immunol 158:275-289

35. Matthews REF (1979) Classification and Nomenclature of Viruses - Third Report of the International Committee on Taxonomy of Viruses. Report prepared by the International Committee on Taxonomy of Viruses and published for the Virology Section of the International Association of Microbiological Societies (IAMS). Intervirology 12:129-296

36. Matthews REF (1982) Classification and Nomenclature of Viruses - Fourth Report of the International Committee on Taxonomy of Viruses. Report prepared by the International Committee on Taxonomy of Viruses and published for the Virology Division of the International Union of Microbiological Societies (IUMS). Intervirology 17:1-199

37. Needleman SB, Wunsch CD (1970) A general method applicable to the search for similarities in the amino acid sequence of two proteins. J Mol Biol 48:443-453

38. Nitzschke E, Rott R (1957) Züchtung des Virus der Bornaschen Krankheit im bebrüteten Hühnerei. Berl Münch Tierärztl Wochenschr 70:101-102

39. Nowotny N, Kolodziejek J, Jehle CO, Suchy A, Staeheli P, Schwemmle M (2000) Isolation and characterization of a new subtype of Borna disease virus. J Virol 74:5655-5658

40. Payne S, Shivaprasad HL, Mirhosseini N, Gray P, Hoppes S, Weissenböck H, Tizard I (2011) Unusual and severe lesions of proventricular dilatation disease in cockatiels (Nymphicus hollandicus) acting as healthy carriers of avian bornavirus (ABV) and subsequently infected with a virulent strain of $\mathrm{ABV}$. Avian Pathol 40:15-22

41. Pringle CR (1996) Virus taxonomy 1996 - a bulletin from the Xth International Congress of Virology in Jerusalem. Arch Virol 141:2251-2256

42. Rinder M, Ackermann A, Kempf H, Kaspers B, Korbel R, Staeheli P (2009) Broad tissue and cell tropism of avian bornavirus in parrots with proventricular dilatation disease. J Virol 83:5401-5407

43. Rott R, Nitzschke E (1958) Untersuchungen über die Züchtung des Virus im bebrüteten Hühnerei unter verschiedenen Bedingungen. Zentralbl Veterinärmed 5:629-633

44. Rubbenstroth D, Rinder M, Kaspers B, Staeheli P (2012) Efficient isolation of avian bornaviruses (ABV) from naturally infected psittacine birds and identification of a new $\mathrm{ABV}$ genotype from a salmon-crested cockatoo (Cacatua moluccensis). Vet Microbiol $161: 36-42$

45. Rubbenstroth D, Rinder M, Stein M, Höper D, Kaspers B, Brosinski K, Horie M, Schmidt V, Legler M, Korbel R, Staeheli P (2013) Avian bornaviruses are widely distributed in canary birds (Serinus canaria f. domestica). Vet Microbiol 165:287-295

46. Rubbenstroth D, Schmidt V, Rinder M, Legler M, Corman VM, Staeheli P (2014) Discovery of a new avian bornavirus genotype in estrildid finches (Estrildidae) in Germany. Vet Microbiol $168: 318-323$
47. Schneemann A, Schneider PA, Kim S, Lipkin WI (1994) Identification of signal sequences that control transcription of borna disease virus, a nonsegmented, negative-strand RNA virus. J Virol 68:6514-6522

48. Schneider PA, Briese T, Zimmermann W, Ludwig H, Lipkin WI (1994) Sequence conservation in field and experimental isolates of Borna disease virus. J Virol 68:63-68

49. Schneider PA, Schneemann A, Lipkin WI (1994) RNA splicing in Borna disease virus, a nonsegmented, negative-strand RNA virus. J Virol 68:5007-5012

50. Schwemmle M, Carbone KM, Tomonago K, Nowotny N, Garten W (2005) Family Bornaviridae. In: Fauquet CM, Mayo MA, Maniloff J, Desselberger U, Ball LA (eds) Virus Taxonomy Eighth Report of the International Committee on Taxonomy of Viruses. Elsevier/Academic Press, San Diego, California, USA, pp 615-622

51. Schwemmle M, Carbone KM, Tomonago K, Nowotny N, Garten W (2011) Family Bornaviridae. In: King AMQ, Adams MJ, Carstens EB, Lefkowitz EJ (eds) Virus Taxonomy - Ninth Report of the International Committee on Taxonomy of Viruses. Elsevier/Academic Press, London, pp 658-664

52. Staeheli P, Sauder C, Hausmann J, Ehrensperger F, Schwemmle M (2000) Epidemiology of Borna disease virus. J Gen Virol 81:2123-2135

53. Staeheli P, Rinder M, Kaspers B (2010) Avian bornavirus associated with fatal disease in psittacine birds. J Virol 84:6269-6275

54. Stenglein MD, Leavitt E, Abramovitch M, McGuire JA, DeRisi JL (2014) Complete genome sequence of a reptile bornavirus recovered from a wild caught Elapsoidea loveridgei. Genome Announc 2:e00779-14

55. Tamura K, Peterson D, Peterson N, Stecher G, Nei M, Kumar S (2011) MEGA5: molecular evolutionary genetics analysis using maximum likelihood, evolutionary distance, and maximum parsimony methods. Mol Biol Evol 28:2731-2739

56. Van Regenmortel MH, Burke DS, Calisher CH, Dietzgen RG, Fauquet CM, Ghabrial SA, Jahrling PB, Johnson KM, Holbrook MR, Horzinek MC, Keil GM, Kuhn JH, Mahy BW, Martelli GP, Pringle C, Rybicki EP, Skern T, Tesh RB, Wahl-Jensen V, Walker PJ, Weaver SC (2010) A proposal to change existing virus species names to non-Latinized binomials. Arch Virol 155:1909-1919

57. Vetten HJ, Haenni AL (2006) Taxon-specific suffixes for vernacular names. Arch Virol 151:1249-1250

58. Weissenböck H, Bakonyi T, Sekulin K, Ehrensperger F, Doneley RJ, Dürrwald R, Hoop R, Erdélyi K, Gál J, Kolodziejek J, Nowotny N (2009) Avian bornaviruses in psittacine birds from Europe and Australia with proventricular dilatation disease. Emerg Infect Dis 15:1453-1459

59. Weissenböck H, Sekulin K, Bakonyi T, Hogler S, Nowotny N (2009) Novel avian bornavirus in a nonpsittacine species (Canary; Serinus canaria) with enteric ganglioneuritis and encephalitis. J Virol 83:11367-11371

60. Wildy P (1971) Classification and Nomenclature of Viruses First Report of the International Committee on Nomenclature of Viruses. S. Karger, Basel

61. Wörz JJ (1858) Die halb-acute Gehirn-Entzündung oder KopfKrankheit der Pferde. Ebner und Seubert, Stuttgart, German Confederation

62. Zimmermann V, Rinder M, Kaspers B, Staeheli P, Rubbenstroth D (2014) Impact of antigenic diversity on laboratory diagnosis of Avian bornavirus infections in birds. J Vet Diagn Invest 26:769777

63. Zwick W, Seifried O (1924) Untersuchungen über die in Hessen gehäuft auftretende seuchenhafte Gehirn- und Rückenmarksentzündung des Pferdes (Borna'sche Krankheit) bei Pferden. Berl Tierärztl Wochenschr 40:465-471 
64. Zwick W, Seifried O, Witte J (1929) Weitere Beiträge zur Erforschung der Bornaschen Krankheit des Pferdes. Arch Wiss Prakt Tierheilkd 59:511-545

65. 堀江真行 [Horie Masayuki], 朝長啓造 [Tomonaga Keizo] (2010) 1. 哺乳動物ゲノムに内在する非レトロウイルス型RNA ウイル
スエレメント1. Endogenous bornavirus elements in mammalian genome]. ウイルス [Uirusu] 60:143-153 